\title{
As pegadas douradas do sensacionalismo no esporte: Mário Filho e a cobertura da Copa de 1930 por Crítica
}

\author{
The golden footprints of sensationalism in sport: \\ Mário Filho and the 1930 World Cup coverage by Crítica
}

\author{
Leda Maria da Costa \\ Universidade Federal Fluminense (UFF), Niterói/Brasil \\ Doutora em Literatura Comparada, UERJ \\ ledamonte@hotmail.com
}

\begin{abstract}
RESUMO: Este artigo objetiva analisar a cobertura da participação da seleção brasileira de futebol na Copa de 1930, realizada pelo jornal Crítica. Enquanto periódicos tradicionais como o jornal $O$ Globo insistiam em uma representação comedida e pedagógica dos fatos esportivos, publicações de cunho sensacionalista como Crítica enfatizavam os aspectos emotivos do futebol. Fazendo uso de estratégias, já comuns na produção de notícias de crimes e tragédias cotidianas, Crítica promove uma cobertura da Copa de 1930 em que se tenta deixá-la repleta de lances de sensação. Nessa cobertura destaca-se o papel de Mário Filho, que no final da década de 1930, assume as páginas esportivas de $O$ Globo dando início à consolidação de seu papel protagonista na história do jornalismo esportivo.
\end{abstract}

PalavraS-CHAVE: Imprensa esportiva; Copa de 1930; Crítica; Mário Filho.

ABSTRACT: This article aims to analyze the coverage of the Brazilian football team participation in the 1930 World Cup held by the Crítica newspaper. While traditional periodicals as the newspaper $O$ Globo persisted on a moderate and pedagogical representation of the sportive facts, sensationalist publications as the Crítica emphasized the emotional aspects of football. The Crítica makes use of the strategy contained in the production of news about crimes and daily tragedies to promote the coverage of the 1930 World Cup, trying to make of it full of sensational episodes. This coverage highlights the importance of Mário Filho, who takes on the sportive pages of $O$ Globo newspaper in the late 1930's, initiating the strengthening of his protagonist part in the sportive press.

KeYwords: Sportive press; 1930 FIFA World Cup; Crítica; Mário Filho. 


\section{INTRODUÇÃO}

Em 2014, o Brasil sediou pela segunda vez uma Copa do Mundo. O mau desempenho da seleção e a derrota para a Alemanha pelo elástico placar de 7 a 1 repercutem até os dias de hoje. ${ }^{1}$ Especialmente no caso brasileiro, as Copas do Mundo exercem papel relevante no processo de construção identitária do país. Após as conquistas dos campeonatos de 1958, 1962 e 1970, o torneio realizado pela FIFA se consolida, no Brasil, como um importante momento ritualístico de construção da identidade nacional. ${ }^{2}$ Essa centralidade torna-se perceptível na cobertura dada pela imprensa às participações da seleção nas Copas do Mundo e na repercussão dos resultados dos jogos. Seja nas rádios, na televisão, no meio impresso ou na internet, os "especialistas"3 divulgam suas opiniões autorizadas e posicionamentos, fazendo do futebol uma grande arena de debates e discussões.

Nessa arena, os jogos e o desempenho da seleção em Copas do Mundo costumam provocar discussões acaloradas. Revolta, tristeza ou um entusiasmo que beira o ufanismo dão a tônica das reportagens que vão para as bancas no dia seguinte a uma partida importante do selecionado nacional. A imprensa esportiva consegue fazer da derrota e da vitória uma fonte de "falação esportiva" constante e duradoura. ${ }^{4}$ Tanto a vitória quanto a derrota podem ter seu efeito mais que redobrado dependendo do tipo de significado com os quais se reveste um jogo. ${ }^{5}$ E é extremamente relevante o papel da imprensa esportiva nesse processo de atribuição, produção e circulação de sentidos que gravitam no universo futebolístico. E essa mediação só tem aumentado com o tempo. A visão que temos de uma partida é amplamente perpassada pela interferência dos meios de comunicação.

\footnotetext{
${ }^{1}$ Sobre o jogo Brasil e Alemanha ver BRINATI, Francisco. Maracanazo e Mineiratzen. Imprensa e Representação da Seleção Brasileira nas Copas do Mundo de 1950 e 2014. Curitiba: Prismas, 2016.

${ }^{2}$ GUEDES. O Brasil não é para principiantes: Carnavais, malandros e heróis, 20 anos depois.

${ }^{3}$ TOLEDO. Lógicas no futebol.

${ }^{4}$ ECO. Apocalípticos e integrados, p. 120.

${ }^{5}$ Sobre as recepções das derrotas da seleção brasileira em Copas do mundo ver: COSTA. Leda. A trajetória da queda: as narrativas da derrota e os principais vilões da seleção brasileira em Copas do Mundo. Tese de Doutorado. Pós-graduação em Letras, UERJ, 2008.
} 
Porém, nem todas as Copas foram alvo de um tratamento hiperbólico da imprensa esportiva, o que em parte demonstra que esse evento adquire importância através de um processo histórico que implica mudanças no campo esportivo nacional, assim como no âmbito do jornalismo esportivo, em consonância com os bons resultados obtidos pela seleção, o que somente passou a acontecer a partir da Copa de 1938. Em parte, esse fenômeno se explica, pois antes desse mundial as participações da seleção em Copas não eram alvo de maior atenção do Governo. ${ }^{6}$ Por sua vez, a imprensa costumava dar um tratamento parcimonioso a esse esporte, o que se faz notar em um discurso comedido e em um tipo de cobertura que, muitas vezes, se limitava a dar informações a respeito da ficha técnica do jogo. ${ }^{7}$ Havia pouco investimento em conteúdos emotivos, privilegiando-se a tentativa de se manter uma imagem do futebol enquanto uma prática esportiva da elite. ${ }^{8}$ Durante as primeiras décadas do século $\mathrm{XX}$, grande parte da imprensa brasileira buscou fazer do futebol, um esporte relacionado a hábitos importados da Europa e que conferia um status de superioridade aos indivíduos que o praticavam.

A falta de incentivo do Governo, assim como uma imprensa ainda atrelada a formas tradicionais de noticiar o esporte, pode justificar o pequeno espaço concedido à cobertura dos jogos da seleção nas Copas de 1930 e 1934. Entretanto, cabe mencionar que esse modo discreto de compor a notícia esportiva era um fenômeno comum aos jornais tradicionais da época. Revistas ilustradas e publicações de cunho sensacionalista, ao contrário de outros periódicos, já investiam em uma abordagem que enfatizava seus principais personagens, alimentando tensões e expectativas em torno de um jogo, enfim representando o futebol através de uma linguagem próxima da que é usada nos dias atuais. ${ }^{9}$

Nesse sentido, destaca-se o jornal Crítica, publicado no Rio de Janeiro e que se tornou famoso pelo alto teor apelativo de suas manchetes e reportagens. Nele, trabalhou Mário Filho, um dos mais importantes nomes da história da imprensa

\footnotetext{
${ }^{6}$ FRANZINI. Corações na ponta da chuteira: capítulos iniciais da história do futebol brasileiro (1919-1938), 2003.

${ }^{7}$ MELO. O esporte na imprensa e a imprensa esportiva no Brasil.

${ }^{8}$ PEREIRA, Leonardo Affonso de Miranda. Footballmania.

${ }^{9}$ SILVA. Mil e uma noites de futebol.
} 
esportiva no Brasil. Em Crítica, Mário Filho esteve à frente da seção esportiva podendo pôr em prática fórmulas de narrar os fatos que, posteriormente, seriam consagradas no jornal $O$ Globo e no Jornal dos Sports. Fórmulas que flertavam com narrativas de matriz melodramática, típicas do discurso que obedece ao "fluxo do sensacional", pois que fazem uso de "temáticas que repetem os mitos e as representações que falam de crimes e mortes violentas, de milagres, de desastres, enfim, de tudo o que foge a uma ideia de ordem presumida". ${ }^{10}$

Nas páginas de Crítica, a linguagem do jornalismo esportivo mostrava-se mais ágil, menos laudatória e se construía a partir do enfoque nos aspectos mais emotivos do universo futebolístico. Seria exagero afirmamos que Mário Filho foi o inventor do jornalismo esportivo, no Brasil. Porém, é possível considerarmos a hipótese de que sua contribuição foi significativa no processo de renovação das técnicas de representação dos acontecimentos vinculados ao esporte.

Em periódicos como Crítica, o futebol recebeu tratamento diferente de veículos tradicionais como $O$ Globo. E esse aspecto se evidencia na cobertura dada à participação da seleção brasileira de futebol na Copa de 1930.

\section{FUTEBOL PEDAGÓGICO}

Nos anos iniciais de sua chegada ao Brasil - especialmente no Rio de Janeiro e São Paulo - as principais formas de apropriação do futebol buscavam imprimir nessa prática esportiva uma imagem relacionada a valores típicos das parcelas sociais mais abastadas da sociedade. Em um período em que se ansiava pela modernização das cidades, o futebol - assim como outros esportes - era visto como veículo civilizador e promotor da regeneração de um povo considerado atrasado. Essa perspectiva relacionava-se diretamente a um contexto que ultrapassava a esfera esportiva. Nesse sentido, é importante lembrar a influência do discurso médico-higienista que se fez presente no Brasil, no final do século XIX e início do $\mathrm{XX}$, e que se refletiu nos discursos em torno das práticas corporais e esportivas. Como nos mostra Lilia Moritz Schwarcz, a esfera científica no país,

\footnotetext{
${ }^{10}$ BARBOSA. O jornalismo popular, a construção narrativa e o fluxo do sensacional, p. 71.
} 
influenciada por algumas correntes antropológicas, preocupava-se com o futuro do Brasil ancorando-se nas teorias da evolução social que no caso brasileiro "se viu diretamente associada ao problema da raça e de suas possíveis implicações". ${ }^{11}$

Não sem motivos, o futebol gerou entusiasmo em Fernando de Azevedo, um dos mais importantes defensores dos ideais eugênicos em contexto educacional. ${ }^{12}$ Ao perceber que muitos colégios, incluindo os religiosos, haviam inserido o futebol no currículo como prática que visava imprimir disciplina em seus alunos, Fernando de Azevedo celebrou afirmando que "A juventude parece ter tido a intuição de que este esporte era o mais completo do ponto de vista educativo e psicodinâmico e por isso recebeu-o de braços e corações abertos como se estivesse esperado por ele há muito tempo".13

A questão racial não se dissociava da social e, nesse processo, os clubes esportivos exerciam função importante no mecanismo de conservação do esporte, entre os quais o futebol, como uma atividade típica de "grupos jovens da elite carioca". ${ }^{14}$ Essa tentativa se tornou ainda mais clara com o gradativo surgimento de entidades responsáveis pela regulamentação e gerenciamento esportivo. No caso específico do Rio de Janeiro, destaca-se a fundação da Liga Metropolitana de Football, em 1907. Nesse mesmo ano, essa entidade esportiva teve seu primeiro estatuto aprovado, deixando claro nesse documento o "rigoroso esquema de seleção, haja vista que, a burocracia para a filiação era grande e, sobretudo, diretamente ligada a quantias em dinheiro, que de certa forma afastava os pequenos clubes".15

Na busca pela manutenção do futebol como um espaço acessível a poucos, a imprensa teve papel importante ao endossar um discurso que interpretava o futebol como uma prática que seria capaz de servir de instrumento civilizador de um país como o Brasil. Para que o futebol pudesse desempenhar esse papel era necessário afastar dele qualquer modo de fruição considerada inadequada à imagem elitizada de um esporte importado da Inglaterra. Daí o imperativo de representá-lo como um esporte no qual deveria prevalecer o cavalheirismo - o fair

\footnotetext{
${ }^{11}$ SCHWARCZ. O espetáculo das raças, p. 92.

${ }^{12}$ SOARES. Educação física: raízes europeias e Brasil.

13 Apud ROSENFELD. Negro, macumba e futebol, p. 78.

14 SANTOS. Memória social dos esportes, p. 36.

${ }^{15}$ SANTOS. Memória social dos esportes, p. 40.
} 
play - em detrimento de qualquer manifestação violenta e, sobretudo, que o associasse a características populares. Não sem motivos, os clubes de futebol costumavam ser alvo da atenção da imprensa que enfatizava os eventos sociais que neles ocorriam, fazendo disso uma espécie de: "celebração do ambiente elitizado do futebol [...] era habitual que os cronistas ressaltassem o ambiente cordial, a participação dos vencidos e vencedores, as presenças ilustres, as homenagens e discursos proferidos pelos representantes dos clubes e da imprensa". ${ }^{16}$

Associada a essa ênfase pedagógica e elitista, havia a questão do nacionalismo manifesto em alguns amistosos internacionais realizados por clubes brasileiros e que se intensificava com a seleção brasileira. E nesse aspecto cabe destacar o ano de 1919, especificamente o Campeonato Sul-Americano, que foi a primeira conquista de relevância do futebol nacional. Esse evento mobilizou a cidade do Rio de Janeiro, o que dava mostras do quanto o esporte vinha ganhando em popularidade. Entretanto, essa popularidade foi alvo de polêmicas e disputas já que pressupunha o risco de uma gradativa - e por muitos, indesejada - aproximação entre as camadas mais ricas e as mais humildes da sociedade em torno do futebol.

Houve por parte da imprensa tradicional carioca uma grande cobertura dada ao Campeonato Sul-Americano de 1919, o que incluía os próprios treinos da seleção brasileira que "eram comentados diariamente nos jornais, assim como o que acontecia com as seleções rivais, em uma cobertura inédita até aquele momento". ${ }^{17}$ Porém, o tipo de discurso adotado privilegiava uma perspectiva pedagógica e eugênica do futebol, compreendendo-o como uma prática capaz de regenerar a raça brasileira. Esse tipo de interpretação defendida por intelectuais como Olavo Bilac e Coelho Neto partia de uma perspectiva vinculada à elite que tomava para si a tarefa de "civilizar" o país por intermédio de uma prática esportiva importada da Europa. Nesse sentido, a vitória da Seleção brasileira sobre os Uruguaios - que lhe deu o título do Campeonato Sul-Americano - foi usada como uma clara demonstração da relação direta entre sucesso esportivo e aprimoramento da raça:

\footnotetext{
${ }^{16}$ SANTOS. Memória social dos esportes, p. 51.

${ }^{17}$ FERNANDEZ. Fluminense Foot-Ball Club, p. 111.
} 
Outras matérias publicadas na imprensa da época igualmente se valeram do sucesso da seleção brasileira para destacar a relação entre o desenvolvimento esportivo do país e o aprimoramento da raça e da nacionalidade. Delas se depreende o vivo desejo de romper com os complexos de inferioridade - racial, social, moral - que perturbavam nossa autoimagem, cujo parâmetro sempre fora a Europa "civilizada". ${ }^{18}$

Em 1922, outro evento esportivo realizado no Rio de Janeiro também chamou a atenção da imprensa e, mais uma vez, o nacionalismo se faz presente. No ano do centenário da Independência realizaram-se os "Jogos Olympicos do Rio de Janeiro"19 dentro da Exposição Universal ${ }^{20}$ daquele mesmo ano. Várias competições foram realizadas entre as quais o Campeonato Sul-Americano de futebol. Ao contrário da seleção de 1919 formada basicamente por jogadores do Rio e de São Paulo, a CBD - Confederação Brasileira de Desportos - mobilizouse para incluir jogadores representantes de diversas partes do Brasil. Esse esforço refletia as cisões políticas do país e as tentativas de minimizá-las por intermédio do futebol:

O projeto foi posto em prática com seleções das federações de estados representantes da política do café-com-leite (São Paulo e Minas Gerais) e da chamada "Reação Republicana", o movimento que tentou derrubar paulistas e mineiros nas eleições presidenciais de 1922 (Rio de Janeiro, Distrito Federal, Bahia, Pernambuco e Rio Grande do Sul). Ainda foram convidados pela CBD as federações do Pará, e do Paraná. O país foi dividido em três zonas geográficas que contavam cada qual com um grupo de equipes. A "Zona Norte" contou com Bahia, Pará e Pernambuco. Como os dois últimos desistiram de participar do torneio, o time baiano classificou-se para as finais, a serem disputadas em São Paulo e Rio de Janeiro. A estranhamente denominada "Zona Centro" foi formada com Rio Grande do Sul e Paraná. Os gaúchos se classificaram após um empate e uma vitória. Cada um desses grupos classificava um torneio final a ser disputado no Rio de Janeiro e em São Paulo. ${ }^{21}$

\footnotetext{
${ }_{18}^{18}$ FRANZINI. Corações na ponta da chuteira, p. 36.

${ }^{19}$ Sobre esse assunto ver SANTOS, João Manuel Casquinha Malaia; MELO, Victor Andrade de. 1922. Celebrações Esportivas do Centenário.

${ }^{20}$ Sobre a Exposição Universal realizada no Rio de Janeiro, em 1922, ver Kessel, Carlos. A vitrine e o espelho: o Rio de Janeiro de Carlos Sampaio. Rio de Janeiro: Secretaria das Culturas/Departamento Geral de Documentação e Informação Cultural/Arquivo Geral da Cidade do Rio de Janeiro, 2001.

${ }^{21}$ SANTOS. “Jogos Olympicos do Rio de Janeiro" no Centenário de 1922 [...], p. 11.
} 
O futebol serviu de palco para disputas políticas em um momento conturbado pelo qual o país passava. E mais uma vez, a vitória em campo - com a conquista do bicampeonato - foi tomada como indício de que o país se mostrava valoroso e capaz de oferecer claras demonstrações de "téchnica do desporto bretão [...] na observância da disciplina desportiva [...] na reciprocidade de gestos [...] de alta cortezia e bem compreendida cordialidade". ${ }^{22}$ Novamente dava-se ênfase ao aspecto disciplinar somado ao tom nacionalista da disputa futebolística. O futebol enquanto símbolo de modernidade era compreendido como algo que "não podia faltar aos anseios de atualização da elite brasileira e que deveria por isso ser praticado por pessoas de igual condição social e racial”. 23

É nesse contexto que o discurso adotado por grande parte da imprensa tradicional precisa ser analisado, o que justifica o tipo de linguagem utilizada, marcada pelo comedimento, pela ausência de excessos verbais e pela "seriedade e rigidez formal". ${ }^{24}$ Nelson Rodrigues ao fazer referência à crônica esportiva das décadas de 1910 e 1920 ressalta a falta de atenção dada ao futebol tanto em termos de espaço ocupado nos jornais e, sobretudo no que diz respeito à linguagem à qual ironicamente Nelson faz referência:

Naquele tempo, os estilistas da seção de esporte assim redigiam a notícia de um Flamengo X Fluminense - "Será levado a efeito amanhã no aprazível field da rua Paissandu, o esperado prélio" etc, etc. E o cronista que conseguia esse nível de estilo se julgava um Proust. ${ }^{25}$

Em oposição à rigidez formal - que caracterizava, sobretudo, a imprensa tradicional - era possível perceber um tratamento diferente dado ao futebol, oferecido por algumas revistas de variedades e os chamados jornais sensacionalistas, desde a década de 1910. Muitas reportagens produzidas por essas publicações se caracterizavam pelo uso de um tom mais humorístico, investindo em charges e casos pitorescos envolvendo jogadores. Como afirmou Marcelino Rodrigues Silva, nessas reportagens começava a ser alimentada uma

\footnotetext{
22 O Imparcial, Rio de Janeiro, 3 out. 1922. Vida Desportiva.

${ }^{23}$ SANTOS. Celebrações esportivas do centenário, p. 63.

${ }^{24}$ SILVA. Mil e uma noites de futebol, p. 91.

${ }^{25}$ RODRIGUES. O homem fluvial, p. 8.
} 
interpretação do futebol "não como pedagogia, mas como diversão [...] em que cabiam as superstições populares, a irreverência, a iconoclastia e as manifestações mais francas das paixões clubísticas e regionais". ${ }^{26}$

As publicações mais populares tinham como marca o farto uso à linguagem visual, através de fotos, charges e de uma diagramação que visava despertar a atenção dos leitores. No que diz respeito às revistas ilustradas é válido lembrar seu sucesso de público no início do século XX. Esse êxito editorial em grande medida se relacionava a estratégias lúdicas de comunicação que jogam com a polissemia entre palavras impressas e imagens. 0 artista J. Carlos, por exemplo, foi autor de diversas dessas charges carregadas de ironia como se pode ver, em uma das edições de Careta $^{27}$ na qual meia página da revista é ocupada pela caricatura do árbitro argentino que apitara o jogo Brasil e Uruguai, válido pela final do SulAmericano de 1922. Cercada da figura de duas belas torcedoras aparece a imagem do árbitro mostrando um sorriso malicioso. J. Carlos fazia alusão a uma possível arbitragem tendenciosa que de tudo fez para facilitar a vitória brasileira. 0 mesmo tom crítico e irônico é perceptível na Careta do dia 28/10/1922 na qual uma charge mostra uma estátua da República, com uma mão na cabeça de franzino Ruy Barbosa. Em outra mão a República oferece um livro a três figuras pequenas de jogadores de futebol lhes dizendo: "Meus filhos! Nada de exageros! Lembrai-vos que a grandeza de uma nação não está nos músculos dos seus athletas, mas na intelligencia de seus intelectuais!" (28/10/1922).

Longe de uma rígida perspectiva nacionalista e pedagógica, o humor e a ironia pontuavam essas publicações populares. Essa mesma linha editorial era seguida por jornais de fluxo sensacionalista (BARBOSA, 2005), ${ }^{28}$ entre os quais destaca-se Crítica, de propriedade de Mário Rodrigues, e onde trabalhavam seus filhos Nelson Rodrigues e aquele que se transformaria no mais importante nome da história da crônica esportiva brasileira: Mário Filho.

\footnotetext{
${ }^{26}$ SILVA. Mil e uma noites de futebol, p. 88.

2707 de junho de 1919.

${ }^{28}$ BARBOSA. O jornalismo popular, a construção narrativa e o fluxo do sensacional, p. 64-87.
} 


\section{O “FLUXO dO SENSACIONAL” EM CRÍTICA}

A vida cotidiana se transformava em espetáculo, fenômeno que no final do século XIX foi uma das marcas de um importante processo de transformação pelo qual o jornalismo nos Estados Unidos passou. Nessa época, o jornalismo fortalecia cada vez mais seus laços com o consumo, transformando-se em negócio que para a obtenção de lucro precisava cativar seus leitores. E para tanto, além de fazer uso da publicidade "os jornais se beneficiavam da experiência da vida cotidiana como espetáculo",29 o que incluía os acidentes e desastres do dia-a-dia.

O aproveitamento da vida cotidiana era perceptível na chamada penny press, tipo de jornalismo que nos Estados Unidos e Inglaterra interessava-se não por opiniões, mas:

pelo que o povo tinha feito, ou pelo menos se dizia ter feito. E não era apenas uma questão de notícia: era também uma questão de esfera da ação [...] os jornais baratos foram os primeiros a reconhecer a importância da vida cotidiana e os primeiros a imprimir 'artigos de interesse humano' [...] Já de início a imprensa barata especializou-se em crimes, sobretudo assassinatos. ${ }^{30}$

Nas décadas de 1910 e 1920, algo parecido ocorre na produção jornalística do Brasil. É nesse contexto que se inserem sucessos como Crítica e Manhã, periódicos que apelavam à fantasia do leitor ao lhes oferecer identificação e familiaridade através de: "tragédias que não puderam ser presenciadas, mas que foram sentidas através de uma narrativa produzida pelos repórteres [...]. A narração dos acontecimentos implica uma integração do leitor àquele mundo". ${ }^{31} \mathrm{~A}$ seção policial ocupava espaço privilegiado, pois, como afirmou Nelson Rodrigues, a imprensa dos anos de 1920 "gostava de sangue".32

Em Crítica, a cobertura feita das tragédias cotidianas contava com o envio de jornalistas ao local onde houvesse ocorrido os crimes, as tragédias ou qualquer acontecimento que pudesse provocar sensação nos leitores. Somado a essa tática é importante destacar o aspecto gráfico do jornal:

\footnotetext{
${ }^{29}$ SCHUDSON. Por que é que as notícias são como são, p. 126.

${ }^{30}$ GABLER. Vida, o filme, p. 63-64.

31 BARBOSA; ENNE. O jornalismo popular, a construção narrativa e o fluxo do sensacional, p. 67-87.

${ }^{32}$ RODRIGUES. O homem fluvial, p. 88.
} 
A profusão de títulos utilizando os mais variados efeitos gráficos [...] faz do jornal [Crítica] uma espécie de caleidoscópio de imagens. Ao lado da feição gráfica inovadora, oferecem ao público como unidade textual um cardápio envolvendo toda espécie de tragédia urbana. ${ }^{33}$

Aquele recurso mencionado por Nelson Rodrigues é sistematizado com a “Caravana Crítica”, composta por repórteres que não apenas tinham como missão registrar os acontecimentos, mas também fazer apuração de denúncias e realizar investigações. $^{34}$ Além das fotografias, Andrés Guevara e Enrique Figueroa produziam caricaturas e eram responsáveis por uma diagramação inovadora e que visualmente produzisse mais impacto aos leitores. Associado a essa estratégia, somavam-se os baixos preços cobrados, o que fez desse periódico um sucesso de vendas da época, algo do qual o próprio jornal costumava vangloriar-se. ${ }^{35}$

0 apelo à visualidade era uma estratégia comum aos jornais de Mário Rodrigues $^{36}$ e que objetivava, como já foi mencionado, atrair a atenção dos leitores, despertar sua curiosidade e, muitas vezes, chocá-los. Mário Filho, ao que parece, incorporou essa tendência típica das notícias policiais e a levou para as notícias esportivas. 0 envio de repórteres aos locais de jogos e até mesmo à casa dos jogadores era prática comum. Essa tática se mostrava importante, sobretudo porque o jornal investia bastante em entrevistas com os atletas, facilitando a inserção de uma perspectiva subjetiva, emotiva e com possibilidade de alimentar algum tipo de polêmica.

\footnotetext{
${ }^{33}$ BARBOSA; ENNE. O jornalismo popular, a construção narrativa e o fluxo do sensacional, p. 67-87.

${ }^{34}$ Crítica chegou mesmo a oferecer serviços especializados em investigação, o "Critica Detetive". Em anúncio, o jornal informa a criação de um bureau "de informações secretas sobre assumptos de toda natureza [...] As informações sobre quaisquer factos ou pessoas devem ser solicitadas pessoalmente a esta redação, onde temos, á disposição um gabinete á parte, reservado (31/08/1929).

${ }^{35}$ Crítica se autointitulava "O matutino de maior circulação do Brasil".

${ }^{36}$ Mário Rodrigues foi um conhecido jornalista no Rio de Janeiro, na década de 1920, sendo proprietário dos jornais $A$ Manhã e Crítica, este último empastelado logo após a Revolução de 1930 que derrubou os aliados de Mário Rodrigues e levou ao poder, seus inimigos políticos. Os jornais de Mário Rodrigues, sobretudo A Manhã, destacavam-se na parte gráfica, que ficava sob responsabilidade do ilustrador Andrés Guevara.
} 
CRITICA Publíca, Hoje, Uma Sensacional Chronica de Floriano Peixoto Corrêa Sobre o America em Buenos Aires

FLORIANO OIZ, EM CHRONICA ESPECIAL PARA oRITICA. QUE DESEJA ARDENTEMENTE A REVANGHE OOS 6 A 1

Onevitavel e o Inesperadio, o sport na Argentina, Buenos Aires, Dyiame de Hermogenes, «EI Negrito",

loel e o Espelho, as Risadas de Feiliç, a Surdez e a

Economia, a "Armação» de Sobral, o Coracão Oue

Ficou no Rio de laneiro e a Visita de CRITICA
Ficono

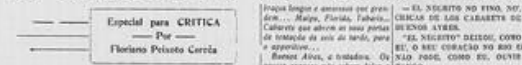

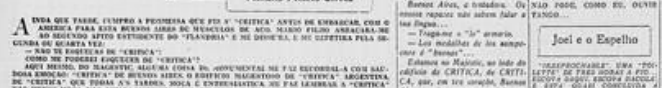

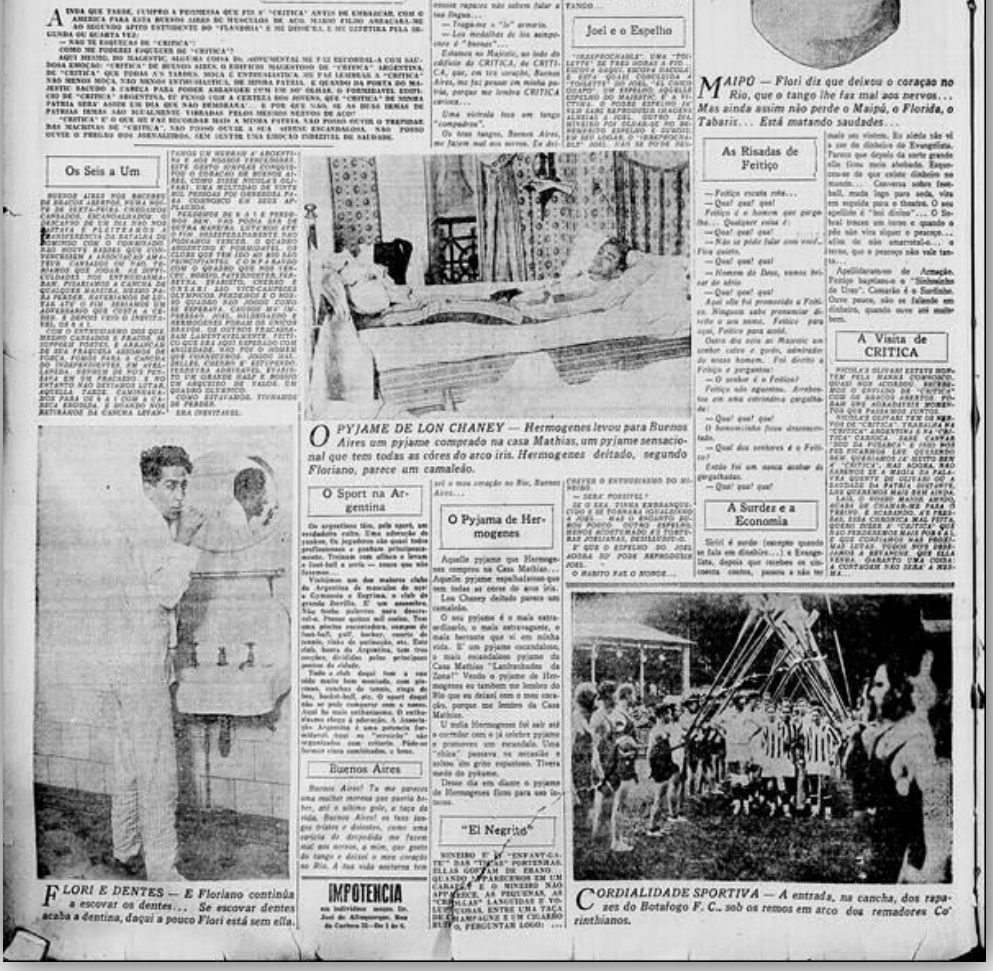

Legenda: Cobertura da Viagem do time do América a Buenos Aires. No canto inferior esquerdo pode-se ver a foto do jogador Floriano Peixoto Correa escovando os dentes (Hemeroteca Digital da Biblioteca Nacional).

Em algumas vezes, os próprios jogadores faziam a vez de cronistas contando detalhes de seu cotidiano como pode ser visto na edição do dia 13 de março de 1928 quando o jornal anuncia que "Crítica publica, hoje, uma sensacional chronica de Floriano Peixoto Corrêa sobre o America em Buenos Aires". A viajem do clube carioca à Argentina recebeu farta atenção do jornal que enviou sua "Caravana Sportiva”, composta por Mário Filho, Nelson Rodrigues e um fotógrafo, para acompanhar o time. Ao longo de alguns dias, o jornal estampou em suas páginas não somente depoimentos, mas fotos de jogadores em momentos de 
privacidade. Flori, como era chamado Floriano Peixoto pelo jornal, é mostrado escovando os dentes e Hermógenes surge deitado numa cama vestido de pijama do Lon Chaney. Nessa cobertura - assim como em outras - enfatiza-se a relação cordial e de amizade mantida entre os jogadores e os repórteres de Crítica, em especial, Mário Filho. Floriano Peixoto, por exemplo, inicia seu texto contando que:

Ainda que tarde, cumpro a promessa que fiz a Crítica antes de embarcar com o America para esta Buenos Aires de músculos de aço. Mário Filho abraçara-me ao segundo apito estridente do Flandria e me dissera e me repetira pela segunda ou quarta vez:

- Não te esqueças de Crítica (13/03/1928, p. 4).

Abril de 1929 foi quando Crítica passou a publicar a coluna "Memórias de um jogador de foot-ball”, na qual um ex-jogador chamado Antonio I. S. M, Rei da pelota, conta sua trajetória nos gramados, o sucesso e a queda que o faz terminar os dias como roupeiro de um clube. Antonio, que se autointitula "um profissional clandestino", assim se apresenta:

- eu fui - principiou o 'seu' Antonio - o melhor centro avante entre todos os centro avantes. Sou Antonio I. S. M, o rei da pelota. Tive aos meus pés: dinheiro, mulheres e gloria. Hoje sou roupeiro de um club. Escute-me! A minha história é um poema de ilusões, de desenganos e misérias (18/04/1929).

A coluna é denominada de romance pelo jornal Crítica, ${ }^{37}$ o que pode ser compreendido não exatamente para um possível caráter ficcional, mas para o fato de se tratar de uma história sobre a qual se faz uso de aspectos emocionais, pitorescos que viabilizam que o público leitor crie identificação com a narrativa e as experiências dos personagens envolvidos. 38 "Memórias de um jogador de football" traça um percurso da decadência de um jogador de futebol, o que em grande medida é derivado de um diálogo com os obstáculos que muitos atletas enfrentavam, sobretudo, devido aos problemas de organização do futebol

\footnotetext{
${ }^{37} \mathrm{Na}$ edição do dia 17/04/1929, Crítica anuncia: "Crítica iniciará amanhã, impreterivelmente, o interessante romance 'Memorias de um jogador de Foot-ball" (grifos meus, Crítica 17/04/1929).

${ }^{38}$ Esse sentido dado à palavra romance será usado também no livro de Mário Filho, Romance do Football, cuja proposta principal foi a de reunir textos com certo grau de independência entre si mas perpassados pela tentativa de contar histórias do futebol a partir de seus principais personagens.
} 
brasileiro, no que se refere ao seu processo de profissionalização. ${ }^{39}$ É válido lembrar que em 1933 foi publicado o polêmico livro Grandezas e Misérias do futebol, obra na qual Floriano Peixoto relata toda dificuldade enfrentada enquanto jogador, as trapaças das quais foi vítima, as promessas financeiras não cumpridas dos dirigentes e a instabilidade econômica na qual vivia, numa época em que o amadorismo no futebol era prática dominante.

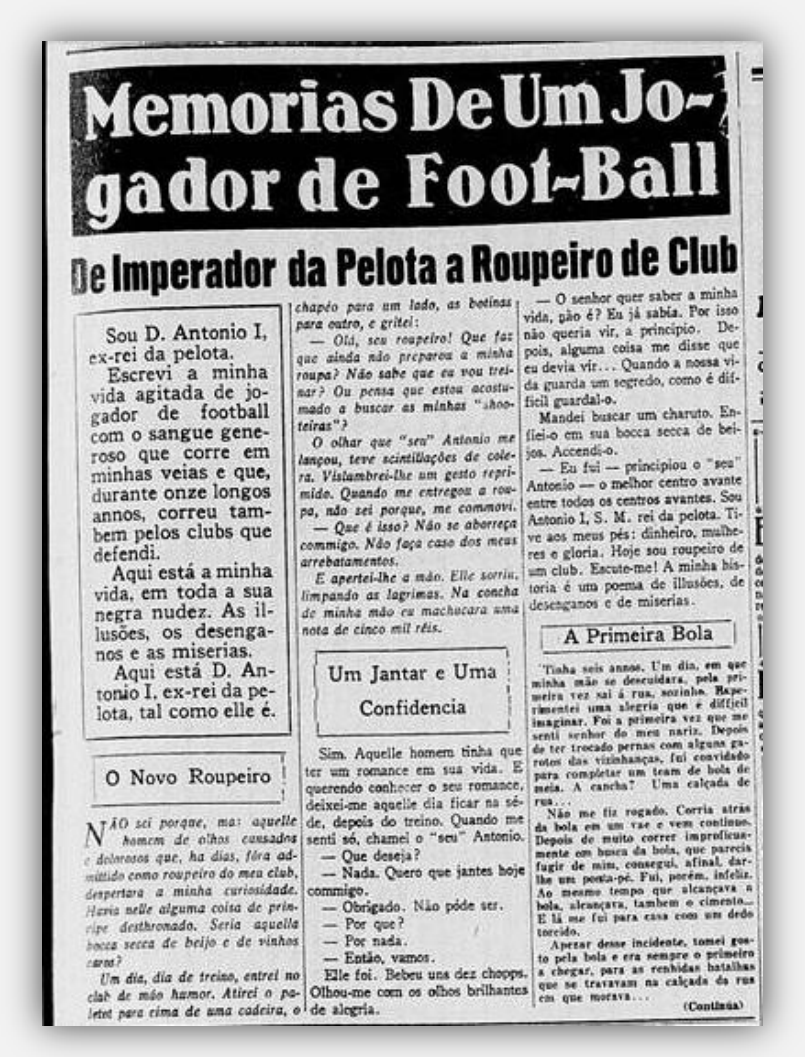

Legenda: Primeira coluna "Memórias de um jogador de foot-ball" publicada dia 14 de abril de 1929. Essa coluna continuou a ser publicada até o final do mês de abril.

Fonte: Hemeroteca da Biblioteca Nacional (https://bit.ly/2JOpgV4).

Também chama a atenção as vezes em que Crítica busca deixar clara a sua popularidade não somente entre os leitores, mas também ao mundo esportivo de um modo geral. Por isso, com orgulho anuncia a fundação do Critica Foot-ball club como uma forma de homenagem ao jornal. 0 clube seria derivado da iniciativa de "um grupo de abnegados 'sportsmen' [...] todos grandes admiradores de Crítica”

${ }^{39}$ Sobre a luta entre os que defendiam o amadorismo e o profissionalismo no futebol ver: PEREIRA. Footballmania, 2000. 
(06/04/1929). Essa relação de admiração foi destaque na festa de aniversário do Crítica, em que "os mais legítimos e destacados representantes de foot-ball brasileiro vieram à nossa redação, beber uma taça de champagne em honra de Crítica. E depois do champagne, os grandes homens de nossa cancha fizeram várias saudações a Crítica e ao chefe da Caravana Esportiva que é Mário Filho" $(12 / 11 / 1929)$.

Conversas por telefone também são publicadas no jornal como sinal de grande familiaridade entre os jogadores e os editores, especialmente, Mário Filho. Essa familiaridade é tanta que às vezes os próprios atletas é que procuram Crítica para confirmar ou não alguma notícia. Esse caso podemos ver na edição do dia 31 de agosto de 1929 quando anuncia-se que o goleiro Joel não atuaria pelo combinado carioca em partida amistosa contra o time português, Vitória de Setúbal. Assim diz o periódico: “Joel, o arqueiro mais guapo do mundo, não joga hoje. Amado vae substituil-o", o que é reiterado pelo próprio jogador que faz uma ligação para o jornal para contar que estava doente:

Hontem, á tarde, o telephone de Crítica, o celebre 5424, tocou

- Prompto

- É Crítica?

- Exatamente, meu caro.

— aqui quem fala é Joel.

- 0 arqueiro mais guapo do mundo, não?

- Talvez. O Mário Filho está?

—É elle mesmo quem fala.

- Como vae você Mario?

- Bem. E como vae o fascinante Joel?

- Mal. Estou doente.

— Não diga.

- Pois é isso mesmo. Estou doente.

- Grippe?

— Não. Uma indisposição, talvez passageira.

- Mas você joga, não é?

- Não posso. Embora ligeiro meu mal impossibilita-me de actuar hoje (31/08/1929).

São vários os exemplos desse processo de exaltação que Crítica faz de si mesmo. Um deles chama a atenção, pois mostra a tentativa de o jornal arrogar para si o mérito da inovação dos modos de representação dos fatos esportivos: 
A imprensa sportiva do Brasil, particularmente, no Rio de Janeiro, há muito que se debatia na ânsia irresistível de se desembaraçar dos methodos arcaicos que caracterizavam o noticiário. Era uma tendencia natural, evolutiva, entravada, todavia, pelo espirito retrogrado de alguns chronistas enraizados, desde as épocas minotaurinas, nos nossos jornaes. [...]

A seção dedicada por Crítica aos interesses do sport constitui, por assim dizer, uma revolução nos meios estagnados da imprensa indígena. [...] Mário Filho, Nelson Rodrigues e Moraes fizeram escola. Hoje grandes e pequenos jornais seguem as pegadas douradas dos precursores do sensacionalismo no sport (29/11/1929).

O periódico buscava deixar claro que tinha contato direto com os jogadores, especialmente, os mais famosos como é o caso de Fausto, "A Maravilha Negra”, e de Prego, o popular atacante do Fluminense. Quando este último ameaça deixar o clube das Laranjeiras, Crítica faz alarde e promove uma campanha para a permanência do jogador, o que incluía o patrocínio de um abaixo-assinado que visava a coleta de assinaturas de torcedores e jogadores pedindo que Prego continuasse no clube no qual havia se formado enquanto atleta e com o qual mantinha vínculos familiares. ${ }^{40}$

Em uma das edições, o jornal publicou uma foto em que aparece o jogador Alfredinho subscrevendo o abaixo-assinado, ao lado de Mário Filho. Além de Alfredinho, Crítica enfatiza que "uma verdadeira romaria de tricolores de coração subiu as nossas escadas para encher o álbum que vamos offerecer a João Coelho Neto, o mais perfeito atleta de todos os tempos do Brasil" (03/04/1929). Em outra edição, a matéria "Tudo por Prego" é ilustrada com uma sequência de fotos na qual aparece Mário Filho, acompanhando os jogadores Ripper, Fernando e Batalha que “accorreram pressurosos á nossa redacção para deixarem suas assignaturas no album que Crítica offerecerá ao grande Prego pedindo para que elle não abandone o Fluminense" (06/04/1929). Quando Prego decide permanecer no time de Laranjeiras, Crítica arroga para si o mérito desse feito:

\footnotetext{
${ }^{40}$ Prego, ou João Coelho Neto, era filho do escritor Coelho Neto que teve intensa participação no clube Fluminense, sendo o compositor do primeiro hino do Clube. Preguinho não somente jogava futebol como representava o Fluminense em competições de polo aquático, natação, remo e outras modalidades.
} 
Prego não abandonou o club que se pode dizer, foi o seu próprio berço. Crítica sente-se feliz em poder dar esta nova alvissareira aos seus leitores, porque foi Crítica o jornal escolhido pelos companheiros de Prego para lançar appello que o levou a desistir dos seus propósitos (Grifos meus, 09/04/1929).

Prego, o filho de Coelho Neto, será um dos protagonistas da cobertura que esse periódico fez da Copa do Mundo de 1930. Nessa oportunidade Crítica adotará as mesmas técnicas de construção da notícia, o que em grande medida, possibilitará que sua cobertura seja muito diferente da oferecida por jornais tradicionais como $O$ Globo. Como o próprio jornal afirmara certa vez, Crítica pode ser pensada como um dos precursores das "pegadas douradas do sensacionalismo no esporte".

\section{A Copa de 30 naS PÁGINAS de CRÍTICA}

Em termos de competição internacional, após a conquista 1922, o desempenho da seleção no Campeonato Sul-Americano se resumiu em um último lugar no ano seguinte, resultado que influenciou na não ida da seleção para a disputa de 1924, desse mesmo campeonato. 0 ano de 1925 marcou a saída do Brasil da disputa do Sul-Americano, decisão que perdurou até o ano de 193241. Portanto após 1925, somente em 1930 a seleção brasileira voltaria a campo em uma disputa internacional de peso, justamente a primeira Copa do Mundo da FIFA, realizada no Uruguai. ${ }^{42}$ Aqui é importante frisar que grande parte do destaque dado à imprensa aos Campeonatos Sul-Americanos de 1919 e 1922 estava diretamente relacionada ao fato de terem sido competições realizadas no Brasil.

Embora a CBD (Confederação Brasileira de Desportos, atual CBF) tenha sido criada em 1916, levou tempo para que esse órgão conseguisse de fato ser uma entidade atuante e representativa para o futebol nacional. Foi somente, em 1937, a

\footnotetext{
${ }^{41}$ SOTER. Enciclopédia da Seleção, p. 46.

${ }^{42}$ De 1926 a 1929 a seleção brasileira não disputou partidas e competições com seleções estrangeiras, jogando somente contra clubes. Os motivos do afastamento da seleção do campeonato Sul-Americano vinculam-se aos episódios de violência e racismo ocorridos nessa competição, em 1925, quando após confusão entre jogadores brasileiros e argentinos, torcedores desses país invadiram o campo gritando "macaquitos" e agredindo fisicamente os atletas brasileiros. O episódio repercutiu muito mal tanto na população quanto em temos diplomáticos, no Brasil. A decisão foi o afastamento da seleção dessa competição (ASSAF; NAPOLEÃO, 2006, p. 34).
} 
partir da intervenção do Estado, na figura de Luís Aranha, que a CBD se transformou em uma instituição cujo objetivo principal seria o de centralizar a administração esportiva do país. ${ }^{43}$ Nos anos anteriores, sem a ação efetiva de uma entidade reguladora, o futebol no Brasil - o que inclui a seleção brasileira - ficou à mercê de federações locais cada qual privilegiando interesses particulares, gerando conflitos que influenciaram decisivamente na participação da seleção no primeiro mundial organizado pela FIFA.

Esse problema foi acompanhado de perto pelo jornal Crítica que em tom de revolta alerta para os prejuízos provocados pela cisão entre as Federações do Rio (AMEA) e de São Paulo (APEA), ${ }^{44}$ cidades de onde vinham os principais jogadores da seleção. Por isso, Crítica afirmou que "O Brasil irá ou não, em julho, ao Campeonato do Mundo? A acção impatriótica da Amea e da Apea, dificultando os passos da Confederação, no problema da organização do nosso Scractch" (Crítica, 03/05/1930). De fato, os problemas de relacionamento entre as duas entidades mais importantes do futebol tiveram como consequência a ausência de jogadores importantes para a composição da seleção. Entre esses jogadores estava o maior ídolo da época, o mulato Friedenreich que atuava pelo Paulistano.

Além dos problemas internos, é necessário também ressaltar que a Copa de 1930 foi uma competição que capitalizou pouco interesse, sobretudo da Europa. Diferentemente de hoje, não houve disputa para a escolha da sede e o Uruguai surgiu como opção certa já que possuía a equipe bicampeã olímpica. Devido a distância e as dificuldades de transporte, vários países europeus se recusaram a vir para a América do Sul, fazendo da Copa de 1930 um torneio quase que de caráter local. ${ }^{45}$ Foram 13 participantes ao total, entre os quais o Brasil. ${ }^{46}$ Trata-se de mais

\footnotetext{
${ }^{43}$ Como afirmou Carlos Eduardo Sarmento, a presença de Luís Aranha "viabilizaria as ações governativas que iriam redesenhar a gestão do desporto nacional” (2006, p. 62). Em relação ao futebol, a CBD, em 1937, firmou acordo com a FBF (Federação Brasileira de Futebol) que na época havia sido reformulada para abrigar os times profissionais do país. A CBD, que desde sua criação era totalmente contrária ao regime profissional, reconheceu a necessidade de instaurá-lo no país e, assim, deu um grande passo rumo ao fim dos conflitos que marcavam o futebol nacional. Desse modo, Luis Aranha pôde colocar em prática seu planejamento, que incluía o "reconhecimento legal do profissionalismo no futebol, pacificação através da submissão de todos a uma entidade central e especialização do gerenciamento de certas modalidades como meio de obter melhorias operacionais" (p. 64).

${ }^{44}$ Sobre esse assunto ver Franzini (2003).

${ }^{45}$ SOTER. Enciclopédia da Seleção.
} 
um fator que contribuiu para a discreta cobertura da participação da seleção nesse evento, oferecida pela imprensa tradicional. Além de o futebol, de um modo geral, ainda ser alvo de pouca atenção por parte da imprensa, a Copa estava longe de representar o espetáculo esportivo dos dias de hoje.

Longe da imprensa tradicional, mas ao que parece perto do público. No dia 02 de julho de 1930, a seleção brasileira mesmo sem seus melhores jogadores embarcou no navio Conte Verde rumo ao Uruguai. ${ }^{47}$ A despedida da seleção foi noticiada na primeira página de Crítica que traz a manchete "Os brasileiros embarcaram hontem, para Montevidéo, onde pretendem realizar uma marcha triumphal". Abaixo vinha uma foto que mostrava uma grande reunião de pessoas descrita como uma "incalculável massa humana que se aglomera na praça Mauá" (03/ 07/1930). Segundo o jornal os jogadores mostram-se emocionados diante de tanto carinho, como é o caso de Fausto que "abre os braços ao redactor do jornal de seu coração" (03/07/1930). Além dele, Prego, também, é aclamado e aparece em foto ao lado de torcedores.

A viagem da seleção motivou a criatividade dos repórteres de Crítica que investiram em uma perspectiva subjetiva dos dias passados a bordo pelos jogadores, ao proporem um percurso pelos bastidores do navio Conte Verde: "Crítica publica hoje uma descripção detalhada e sensacional da viagem dos brasileiros, segundo o diário de bordo de um jogador" (grifos meus, Crítica, 12/07/1930). A viagem da seleção é narrada a partir da ênfase em episódios pitorescos e bem-humorados, como por exemplo a noite de jogatina liderada por Fausto que, segundo o jornal, provocou "balburdia. Quasi todos se offereceram para tomar parte na jogatina esboçada" (Crítica, 12/07/1930). Além da jogatina, faz-se referência a casos como o do jogador Oscarino que teria lavado seu rosto em um bidê, após confundi-lo com uma pia ou o caso de Itália cujo enjoo o deixou com a pele verde (Crítica, 12/07/1930). 0 humor da noite anterior "desappareceu e foi

\footnotetext{
${ }^{46}$ Uruguai, Peru, Argentina, México, Chile, Brasil, Bolívia, Paraguai, México, lugoslávia, Romênia, Bélgica e EUA.

${ }^{47}$ A briga entre as Federações de São Paulo e Rio de Janeiro inviabilizou a formação de uma seleção composta por seus melhores jogadores, como por exemplo, 0 artilheiro Arthur Friedenreich. Sobre essa questão ver Franzini (2003).
} 
substituído por uma tristeza tétrica. Itália ainda não se curou do enjoo. Está verde (Crítica, 12/07/1930)".

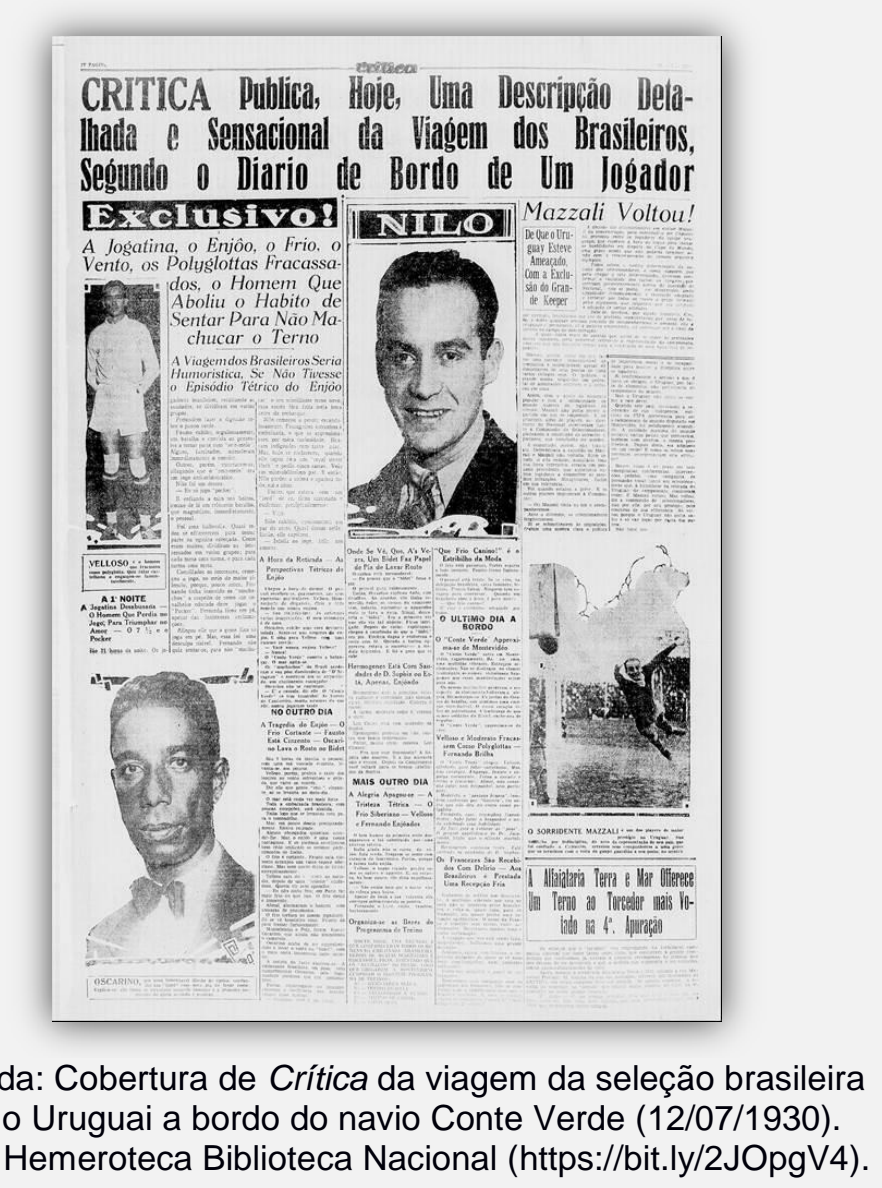

A estreia do selecionado ocorreu dia 14 de julho e foi noticiada pelo jornal $O$ Globo em primeira página. Com uma sequência de fotos dos jogadores trajados de terno e gravata, o jornal carioca anunciou com uma longa manchete: "0 selecionado se lança hoje, nos campos de Montevidéo, á conquista da primeira etapa para a grande victoria do Campeonato Mundial de Football!" (14/07/1930). Além de se exaltar o retorno aos gramados internacionais da seleção brasileira, deseja-se sorte para o jogo contra a Iugoslávia. Embora posta em primeira página, tratava-se de uma breve notícia escrita em linguagem curta e rebuscada, o que se faz ressaltar no recurso à sintaxe de ordem inversa conferindo mais sofisticação e dificuldade de entendimento ao leitor. Além disso, mais uma vez, é possível notar a ênfase na valorização da disciplina dos jogadores, explicitada no "garbo e a limpeza 
de jogo que sempre nos ufanamos para melhor recomendação dos sentimentos communs de lealdade da nobresa desportivos" (O Globo, 14/07/1930).

Crítica, por sua vez, fez uso do "culto ao superlativo", 48 comum aos jornais que seguem uma linhagem sensacionalista, enaltecendo a participação da seleção em uma reportagem repleta de fotos e depoimentos assinados por jogadores e que teriam sido feitos exclusivamente para aquele jornal. 0 jogador Theóphilo enviou um recado assinado à Crítica afirmando que "Vamos encontrar pela frente 'cracks' perfeitos, príncipes da pelota, mas os nossos adversarios são morosos demais e a arrancada brasileira é irresistível" (13/07/1930). Porém, essa promessa já se mostra difícil de ser cumprida logo no início do campeonato. Derrotado pela seleção da Iugoslávia, o Brasil evidencia suas fragilidades. Esse fracasso em campo foi noticiado de modo parcimonioso pelo jornal $O$ Globo que após mencionar a vitória da Argentina sobre a França, afirma que a derrota da seleção era para ser lamentada, porém devia-se elogiar a atuação dos jogadores, pois "a equipe brasileira é excellente tendo, porém, lutado contra a má sorte" $(O$ Globo, 15/07/1930).

Já Crítica opta por um tom de revolta estampando, em sua primeira página, a manchete "Foi a política infame da CBD que arrastou o Brasil á derrota" (15/07/1930). Além desse tom alarmista, o jornal adota uma postura pouco comum para a imprensa na época: a busca pelos responsáveis de uma derrota da seleção brasileira. ${ }^{49}$ Um dos jogadores mais criticados foi o goleiro Joel considerado como "o maior responsável pela derrota do Brasil. Quando balançaram pela $2^{\underline{a}}$ vez as redes do arco entregue á sua guarda, elle estava despreocupadamente conversando. $01^{\text {o }}$ goal também se deve a sua indecisão" (15/07/1930). 0 atacante Nilo, segundo Crítica, "jogou com um medo flagrante, com preocupação quasi exclusiva de não se expor" (15/07/1930). Já o atacante Prego

\footnotetext{
${ }^{48}$ NEVEU. Sociologia do jornalismo, p. 121.

${ }^{49}$ Sobre esta questão ver COSTA, Leda M. A trajetória da queda: as narrativas da derrota e os principais vilões da seleção brasileira em Copas do Mundo. Tese de Doutorado em Literatura Comparada, UERJ, 1998.
} 
teve uma atuação considerada nervosa, porém o jornal também reconhece que ao menos o jogador merecia elogios, pois foi dele o primeiro e único gol da seleção. ${ }^{50}$

Dois dias depois, Crítica publicou um depoimento do jogador Hermógenes que, de acordo com o correspondente do jornal, havia confessado que a seleção havia perdido por causa do frio que fazia em Montevidéu. A baixa temperatura teria provocado "entorpecimento dos membros, enregelados e insensibilizados até ao contacto com a bola" (17/07/1930). Essa versão da derrota carrega consigo certo tom de subjetividade proporcionada, em grande medida, por ter sido derivada de um depoimento dado pelo jogador ao jornal. Três dias depois, Crítica volta a publicar uma entrevista de Hermógenes que insiste nos problemas causados pelo frio, enfatizando, ainda mais, certos detalhes pitorescos provocados pela baixa temperatura como, por exemplo, o medo de os jogadores tomarem banho:

Hermógenes não se esqueceu de Crítica quando elle saltou no caes. A primeira idéa que elle teve foi ir para a casa onde mora com a família. Logo a seguir como não podia deixar de acontecer, elle se lembrou do jornal de seu coração e assumiu de si para si o compromisso formal de o visitar, quanto antes.

Assim depois de ter abraçado os seus, Hermogenes rumou para a nossa redacção. Hermogenes, então, falou nestes termos:

- o factor maior da nossa derrota foi o frio: um frio inclemente, sádico, anniquilante, Basta dizer que raros brasileiros se submeteram a prova terrível do banho. Nesse particular, não será exagero dizer que batemos o 'record' de permanencia fora dagua porque tomar banho em Montevideo no inverno é um heroismo de que nem todos são capazes (Crítica, 20/07/1930).

Mais uma vez é notável a ênfase no caráter de familiaridade que o jornal mantinha com os jogadores. Essa proximidade também funcionava como um modo de conferir uma imagem de credibilidade ao jornal. Esse aspecto se evidencia, por exemplo, no retorno da seleção ao Brasil. Nessa oportunidade, Crítica mostra a foto do atacante Prego ao lado de dois redatores do jornal. Abaixo dessa fotografia

\footnotetext{
${ }^{50}$ Prego, também conhecido como Preguinho, foi autor do primeiro gol da seleção brasileira em Copas do Mundo. Ele era filho do escritor Coelho Neto um dos grandes entusiastas das práticas esportivas no Brasil e que teve relação direta com o Fluminense, sendo o compositor do primeiro hino do clube.
} 
podemos ler: "Crítica foi o primeiro jornal que Prego abraçou, quando saltou no Rio, hontem elle veio a nossa redacção abraçar, um por um, os seus bons amigos de Crítica. Prego concedeu-nos sensacional entrevista" (grifos meus, 28/07/1930).

A cobertura de Crítica não se limitou à participação da seleção brasileira. Na edição do dia 16 de julho, uma página inteira é dedicada a vitória da Argentina sobre a França, considerada injusta pois que "O jogo dos Argentinos foi inferior, desleal" e "a superioridade dos Francezes foi incontestável" (16/07/1930). Em outro momento Crítica anuncia que partes do jogo entre Iugoslávia e Bolívia seriam irradiadas diretamente da redação do jornal. ${ }^{51}$ A final do campeonato mundial, por sua vez, foi apresentada a partir de um farto recurso fotográfico, destacando-se o Estádio Centenário que é mostrado em perspectiva aérea (29/07/1930). No dia seguinte, a conquista Uruguaia é exaltada com a manchete "Depois de uma batalha de gigantes, plena de lances de sensação, os Uruguayos derrotam os Argentinos por 4 a 2" (31/07/1930). Os principais lances do jogo são descritos e brevemente analisados sendo que o título celeste é interpretado como uma vitória da técnica uruguaia contra o "ardor dos argentinos" (31/07/1930).

Com o fim da Copa, as atenções se voltam para uma partida entre Brasil e França que seria realizada em São Paulo. Aquela mesma França que atuou no campeonato mundial aceita disputar um amistoso contra a seleção nacional, evento que Crítica promove afirmando que "França e Brasil é a formidável batalha nocturna de sexta-feira" (10/07/1930). No dia seguinte, o jornal propagandeia esse jogo como aquele que "Vae arrastar toda cidade, amanhã, de noite á cancha tricolor" (31/07/1930). Formado por um combinado de paulistas e cariocas, a seleção brasileira venceu os franceses por 3 a 2 . A partida foi detalhadamente comentada pelo jornal que destacou os principais momentos, sobretudo, o gol do jogador Friedenreich, descrito lance a lance (02/08/1930). Poucos dias depois a seleção nacional enfrentaria o clube Beogradski F. C., representante da Iugoslávia

\footnotetext{
${ }^{51}$ A primeira transmissão completa de um jogo de futebol foi feita por Nicolau Tuma da Rádio Sociedade Educadora Paulista (primeira emissora de São Paulo, fundada em 1923). Antes, algumas tentativas de transmissão haviam sido feitas. É possível, mas não garantido, que Crítica tenha tentado transmitir jogos de futebol. Porém, essa transmissão não foi a do jogo completo. Sobre a história do jornalismo esportivo na rádio, é recomendado o livro $A$ bola no ar, de Edileuza Soares, 1994.
} 
que havia eliminado o Brasil da Copa de 1930. Crítica exalta esse jogo como sendo uma oportunidade de revanche "tão impacientemente ansiada por todos os brasileiros" (6/08/1930).

Para acompanhar essa partida, Jules Rimet veio ao Rio de Janeiro. 0 então presidente da Fifa aparece, em fotografia, ao lado do caricaturista Nassara, responsável pelas ilustrações de Crítica. Além da foto, publica-se um autógrafo de Rimet dedicado ao jornal. Na matéria sobre esse encontro é narrada a conversa mantida com Rimet, na qual destacam-se os elogios do presidente ao futebol brasileiro e às iniciativas do jornal na promoção do futebol (12/08/1930). Na edição seguinte, o "Sr. Rimet" aparece nas tribunas de São Januário, ao lado do Presidente da AMEA sendo fotografado por Crítica que estampa essa imagem na cobertura que fez da partida vencida pelo selecionado brasileiro contra os Iugoslavos (13/08/1930).

Quando a Copa de 1930 se inicia, a família Rodrigues ainda estava sob efeito de duas fatalidades, a morte do filho mais novo, Roberto Rodrigues, e do próprio Mário Rodrigues. ${ }^{52}$ Crítica estava sob comando de Mário Filho e do irmão Milton Rodrigues. Enquanto conferia emoção e polêmica ao noticiário esportivo, Crítica fazia o mesmo com a representação dos fatos cotidianos, sobretudo, os vinculados à violência e à política. Manchetes dando conta de estupro de menores, assassinatos cruéis e suicídios ocupavam as primeiras páginas acompanhadas de ilustrações que tentavam reproduzir as cenas dos crimes, em seus detalhes mais sórdidos. Em termos políticos, o jornal seguiu mostrando apoio incondicional ao presidente Washington Luiz e seu sucessor Julio Prestes que nas urnas venceu o candidato Getúlio Vargas. Porém, os oposicionistas, alegaram fraude na eleição e em 03 de outubro de 1930 deu-se início a um movimento que visava depor Washington Luiz antes que a presidência fosse transferida a Júlio Prestes. No dia 24 daquele mesmo mês uma junta militar afastou Washington Luiz do governo e no dia 3 de novembro o governo passa às mãos de Getúlio Vargas. Dias depois os

\footnotetext{
${ }^{52}$ Em 1929, o desenhista e ilustrador Roberto Rodrigues morreu assassinado com um tiro disparado por Sylvia Thibau desejosa de se vingar de uma matéria de Crítica que colocava sua honra em questão.
} 
jornais que faziam oposição a Getúlio foram fechados, entre eles, Crítica, que reabriu dias após ter tido sua redação invadida e quebrada.

Mário Filho, juntamente com parte da equipe de Crítica, passa a trabalhar na redação esportiva de $O$ Globo, onde imprimirá técnicas de reportagens e de representação dos fatos, próximos ao que usava no jornal de seu pai. A página 8 de O Globo capitaneada por Mário Filho será responsável por uma cobertura inovadora da Copa de 1938 e nela o jornalista investirá em biografias dramatizadas dos principais jogadores da época, romanceando suas vidas e fortalecendo o laço de familiaridade entre torcedor e ídolo. Nesse mesmo jornal nascerá a coluna "De primeira Fila”, mantida por sete anos e que servirá de base para a construção do livro $O$ negro no futebol brasileiro, publicado em 1949.

\section{REFERÊNCIAS}

ASSAF, Roberto; NAPOLEÃO, Antonio Carlos Napoleão. Seleção brasileira: 1914-2006. Rio de Janeiro: Mauad, 2006.

BARBOSA, Marialva; ENNE, Ana Lucia Silva. O jornalismo popular, a construção narrativa e o fluxo do sensacional. Eco-Pós, v. 8, n. 2, ago.-dez., 2005, p. 67-87. CRÍTICA. Rio de Janeiro, 1930.

ECO, Umberto. Apocalípticos e integrados. São Paulo: Perspectiva, 1998.

FERNANDEZ, Renato Lanna. Fluminense Foot-Ball Club: a construção de uma identidade clubística no futebol carioca (1902-1933). Fundação Getúlio Vargas Centro de Pesquisa e Documentação de História Contemporânea do Brasil - CPDOC Curso de Mestrado em História, Política e Bens Culturais. Rio de Janeiro, 2010.

FRANZINI, Fábio. Corações na ponta da chuteira: capítulos iniciais da história do futebol brasileiro (1919-1938). Rio de Janeiro: DP\&A, 2003.

GABLER, Neal. Vida, o filme: como o entretenimento conquistou a realidade. Trad. Beth Vieira. Companhia das Letras, São Paulo, 2000.

GUEDES, Simoni Lahud. Malandros, caxias e estrangeiros no futebol: de heróis e anti-heróis. In: GOMES, Laura Graziela; BARBOSA, Livia; DRUMMOND, José Augusto (org.). O Brasil não é para principiantes: carnavais, malandros e heróis, 20 anos depois. Rio de Janeiro: Fundação Getúlio Vargas, 2000.

MELO, Victor Andrade de. Causa e consequência: esporte e imprensa no Rio de Janeiro do século XIX e década inicial do século XX. In: HOLLANDA, Bernardo Buarque de; MELO, Victor Andrade de. $O$ esporte na imprensa e a imprensa esportiva no Brasil. Rio de Janeiro: 7 Letras/Faperj, 2012. 
NEVEU, Érik. Sociologia do jornalismo. São Paulo: Loyola, 2006.

PEREIRA, Leonardo Affonso de Miranda. Footballmania. Rio de Janeiro: Nova Fronteira, 2000.

RODRIGUES, Nelson. O homem fluvial. In: FILHO, Mário. O sapo de Arubinha: os anos de sonho do futebol brasileiro. Ruy Castro (org. e sel.). São Paulo: Companhia das Letras, 1994.

ROSENFELD, Anatol. Negro, macumba e futebol. Rio de Janeiro: Perspectiva, 1993.

SANTOS, João Manuel Casquinha Malaia. "Jogos Olympicos do Rio de Janeiro" no Centenário de 1922: olhares sobre a política de um projeto de unificação e celebração da nação através do esporte. Anais do XXVI Simpósio Nacional de História - ANPUH, São Paulo, julho 2011. Disponível em: http://goo.gl/nHPZwn.

SANTOS, João Manuel Casquinha Malaia. O Rio de Janeiro e os jogos de 1922: economia de um projeto esportivo. In: SANTOS, João Manuel Casquinha Malaia; MELO, Victor Andrade de. Celebrações Esportivas do Centenário. Rio de Janeiro: 7Letras/Faperj, 2012.

SANTOS, Ricardo Pinto dos. Uma breve história social do Esporte no Rio de Janeiro. In: SILVA, Francisco Carlos T. da; SANTOS, Ricardo P. dos (org.). Memória social dos esportes - futebol e política: a construção de uma identidade nacional. 1. ed. Rio de Janeiro: Mauad, Faperj, 2006.

SARMENTO, Carlos Eduardo. A regra do jogo: uma história institucional da CBF. Rio de Janeiro: FGV, 2006.

SCHUDSON, Michael. Por que é que as notícias são como são. Revista de Comunicação e Linguagem, n. 8, Centro de Estudos de Comunicação e Linguagens, Lisboa, 1998.

SCHWARCZ, Lilia Moritz. O espetáculo das raças. Companhia das Letras, 2003.

SILVA, Marcelino Rodrigues da. Mil e uma noites de futebol. Belo Horizonte: Editora UFMG, 2006.

SOARES, Carmen Lucia. Educação física: raízes europeias e Brasil. 2. ed. revista. Campinas: Autores Associados, 2001.

SOTER, Ivan. Enciclopédia da Seleção: as seleções brasileiras de futebol, 1914-2002. Rio de Janeiro: Folha Seca, 2002.

TOLEDO, Luiz Henrique de. Lógicas no futebol. São Paulo: Huicitec, 2002. 